\title{
Mediating role of corporate volunteering between entrepreneurial attitude and work engagement
}

\begin{abstract}
BACKGROUND
Work engagement and corporate volunteering attract significant interest among researchers. The entrepreneurial attitude is missing in research among diverse characteristics of employees predicting work engagement. The aim of the study is to fill this gap by verifying the model of the mediating role of corporate volunteering (work characteristics) between the entrepreneurial attitude (employee characteristics) and work engagement.
\end{abstract}

\section{PARTICIPANTS AND PROCEDURE}

Utrecht Work Engagement Scale (UWES-17), an abridged version of the Entrepreneurial Attitude Orientation questionnaire (EAO), the Scale of Corporate Volunteering, and the Scale of Satisfaction with Financial Situation were applied in the study. The sample consisted of 111 employees of the public (27\%) and business sectors (73\%). The sample consisted of $42 \%(n=47)$ women and $58 \%(n=64)$ men aged from 23 to 61 years.

\section{RESULTS}

The model of work engagement was successfully verified. The entrepreneurial attitude proved to be a strong predic- tor of work engagement and corporate volunteering. Corporate volunteering plays a mediating role between the entrepreneurial attitude and work engagement. Seniority and age, unlike in global studies, correlated negatively with corporate volunteering. Public sector employees were less engaged in work (lower Vigor and Absorption). However, their dedication to work was at the same level as employees in the business sector.

\section{CONCLUSIONS}

Work enhanced with corporate volunteering leads to stronger work engagement, and thus to a psychologically healthier workplace. Measurement of the entrepreneurial attitude can be applied in the employee selection process as a predictor of work engagement.

\section{KEY WORDS}

work engagement; seniority; entrepreneurial attitude orientation; corporate volunteering; satisfaction with financial situation

ORGANIZATION - Faculty of Medicine, University of Technology, Katowice, Poland

AUthors' Contributions - A: Study design - B: Data collection - C: Statistical analysis - D: Data interpretation .

E: Manuscript preparation - F: Literature search - G: Funds collection

CORRESPONDING AUthor - Dominika Ochnik, Ph.D., Faculty of Medicine, University of Technology, 43 Rolna Str.,

40-555 Katowice, Poland, e-mail: dominika.ochnik@gwsh.pl

TO CITE THIS ARTICLE - Ochnik, D. (2021). Mediating role of corporate volunteering between entrepreneurial attitude

and work engagement. Health Psychology Report, 9(4), 349-357. https://doi.org/10.5114/hpr.2020.98665

RECEIVED 19.05.2020 • REVIEWED 23.06.2020 • ACCEPTED 30.07.2020 • PUBLISHED 07.12.2020 


\section{BACKGROUND}

Work engagement (Łaguna et al., 2015) and corporate volunteering (Grant, 2012) constitute vital issues developed in the framework of positive organizational psychology. The issue of entrepreneurial attitude rarely emerges in this context. However, it is the entrepreneurial attitude that truly includes initiative and proactivity which may manifest both in corporate volunteering and the enhancement of work engagement. The objective of the present study was to bridge the present research gap by verifying the mediating role of corporate volunteering between the entrepreneurial attitude and work engagement.

The following work characteristics constitute factors which precede the emergence of work engagement; autonomy, diversification of tasks, significance of tasks, problem solving, work complexity, feedback, physical characteristics and working conditions, social support (Christian et al., 2011). The authors consider the transformational style and the leadermember exchange (LMX) theory as factors linked with management. The following were classified as dispositional factors: scrupulosity, positive disposition, proactive personality. The proactive personality is directly associated with motivation (Judge \& Ilies, 2002). The engagement model (Christian et al., 2011) was based on the premise that work characteristics, leadership and dispositional characteristics are directly linked with work engagement and indirectly linked with work performance. In such a context, work characteristics and the features of the individual will have a stronger effect on work engagement levels.

Work engagement exerts an effect on work performance (Bakker \& Bal, 2010) and organizational success viewed in the categories of higher productivity, lower absence, and lower accident rate (Harter et al., 2002). People engaged in work affect the level of engagement among co-workers in the course of modelling (Van Knippenberg, 2000). They are also characterized by a higher organizational commitment (Kim et al., 2017). In addition, work engagement is associated with psychological factors, e.g. mental health of managers (lack of occupational burnout and workaholism) (Schaufeli et al., 2008), and indirectly with health (Zalewska, 2020). Consequently, occupational burnout is negatively correlated with work engagement. Studies revealed that burnout may accompany both very low and very high work engagement (Derbis \& Baka, 2011).

\section{CORPORATE VOLUNTEERING}

Corporate volunteering is one of the initiatives undertaken in the framework of corporate social responsibility. However, it pertains to the perspective of the employee and not the organization itself
(Wood, 2007). This is convergent with the modern understanding of an individual's actions in the organization. It is one of the most rapidly developing volunteering initiatives (Grant, 2012).

In the Polish literature, "employee volunteering" (Grabus \& Rogowska, 2016) is the most frequently applied term. It often emerges in management science, and more seldom in occupational psychology. Since involvement in volunteering is offered and supported by the organization, the term "corporate volunteering" seems more valid and shall be consequently used in the present paper.

The most frequently undertaken scope of studies in the field includes the motivation and predispositions of employees undertaking the activity (Grant, 2012), corporate volunteering from the perspective of outcomes for the individual (Jones \& Kramar, 2010), and intentions positively correlated with behavior (Grant, 2012; Rodell et al., 2017). Permanent participation in corporate volunteering enhances affective commitment to the organization by reverse emancipation of the pro-social identity (Boštjančič et al., 2018). However, the prosocial activity reinforces participation in the corporate volunteering, which is also associated with a higher level of delivered duties (Rodell et al., 2016). Involvement in volunteering activities at a workplace is motivated by the interest in expressing vital personal values, which are positively correlated with organizational commitment. The latest studies (Boštjančič et al., 2018) revealed a positive relationship between work engagement and corporate volunteering.

\section{ENTREPRENEURIAL ATTITUDE}

The attitude constitutes a relatively permanent tendency to a positive or negative valuation of an object (person, item, idea) (Wojciszke, 2011). Classical theories are based on a ternary definition of the attitude. The constituting elements comprise emotional, cognitive, and behavioral components. The attitude may serve various functions: orientational, instrumental, value expression, socio-adaptive, and ego-defending. The attitude may change in time and in relation to a situation via an interactive relation with the environment. It may also serve as a predictor of prospective behaviors (Wojciszke, 2011). It seems that the assessment of entrepreneurship on the basis of the attitude enables the specifics of the issue to be grasped more effectively, as opposed to the personality theory or demographic approach (Krueger et al., 2000). The effectiveness of the personality theory may be decreased in the course of the assessment of general features, which are broader than the construct of entrepreneurship itself. Therefore, the theoretical accuracy of the approach may be considered to be lower (Mitchell et al., 2002). On the other hand, the attitude theory enables entrepreneurship to be examined. However, it requires a theoretical 
model encompassing both the impact of the surrounding environment and that exerted upon the environment by interactions (Robinson et al., 1991). The attitude theory may be applied in order to assess the entrepreneurial attitude. Robinson et al. (1991) were the first to develop an entrepreneurial attitude model. The model encompasses four key constructs: need for business achievements; innovation in business; internal locus of control in business, and self-assessment. The need for business achievements pertains to the perception and delivery of specific business actions in an original, exceptional manner. The internal locus of control pertains to the perception of an individual's influence on business activities (Robinson et al., 1991). It is associated with self-confidence, commitment and pursuit of one's objectives related to entrepreneurship (Choe et al., 2013). Self-assessment denotes self-confidence and perception of one's own business competence (Robinson et al., 1991). It also provides motivation for further effort required to achieve an objective (Douglas \& Shepherd, 2000). It turns out that the assessment of the entrepreneurial attitude enables one to differentiate among entrepreneurs and those who are not. A relationship between entrepreneurial attitudes and intentions exists (Douglas \& Shepherd, 2000). For that reason, a premise can be made that a high level of entrepreneurship constitutes an adequate determinant of entrepreneurial behavior. In addition, entrepreneurial attitudes are positively correlated with organizations' economic performance (Choe et al., 2013). The emotional aspect of the entrepreneurial attitude and innovativeness increases during exposure to information concerning an economic crisis. This explains the proactive and creative attitude of the entrepreneurial in crisis situations (Ochnik, 2016). The entrepreneurial attitude is also a factor enhancing leadership vocational interests (Ochnik, 2018).

\section{PARTICIPANTS AND PROCEDURE}

\section{RESEARCH MODEL}

The present study examines the mediating role of corporate volunteering between the entrepreneurial attitude and work engagement. The work engagement model (Christian et al., 2011) is based on the premise that the significance of work characteristics and the dispositional characteristic (proactivity) exert a direct effect on the development of work engagement. Based on that premise, the effect of dispositional characteristic (entrepreneurial attitude) on work engagement has been hypothesized. The work engagement model (Christian et al., 2011) assumes that both job characteristics and dispositional characteristics are distal antecedents of job performance, that is mediated by work engagement. In this study, the main aim was to reveal whether work engagement is predicted by entrepreneurial attitude (dispositional characteristic) and also whether that relation is mediated by the work characteristic - corporate volunteering. The Volunteer Work Design Model (Grant, 2012) was also taken into consideration. It shows that participation in corporate volunteering might be a part of work design and can be shaped by volunteering task characteristics. Additionally research shows a positive relationship between work engagement and corporate volunteering (Boštjančič et al., 2018). Therefore the author's model is based on the premise that repeated participation in corporate volunteering boosts work engagement. Due to the fact that the entrepreneurial attitude has not been examined in the context of corporate volunteering and work engagement, the following thesis was assessed: entrepreneurial attitude, as a feature of an individual, exerts a direct effect on the increase of work engagement, including via a characteristic associated with the enriched volunteering project design - participation in corporate volunteering. Therefore, it was hypothesized that corporate volunteering plays a mediating role between entrepreneurial attitude and work engagement.

In addition, a premise was made that gender may diversify the entrepreneurial attitude (Ochnik, 2018) and work engagement (Schaufeli \& Bakker, 2003) in favor of men. Moreover, the diversification of variables in terms of public vs business sector employment was evaluated. The premises were presented in the work engagement model in Figure 1.

\section{PROCEDURE}

The study was conducted online and by means of the traditional paper-pencil approach (10\%). The survey was usually completed in 20 minutes. The paper-pencil data collection referred to public sector employees - mine rescuers. The invitation to the online study was sent via email to employees and human-resources departments in the Silesian region. The participant defined the sector type only, so as to conform to the anonymity rule. The study adhered to ethical requirements pertaining to the anonymity and voluntariness of participation.

\section{PARTICIPANTS}

The sampling was purposive and the selection criterion was being an employee in the Silesian region. The entrepreneurs were excluded from collecting data. The study encompassed 111 workers employed in the Silesian region. The public sector was represented by $27 \%$ of respondents and the business sector by $73 \%$. The sample was multi-occupational. Positions in public sector $(n=30)$ were: mine rescuer $(33 \%)$, teacher (33\%), warehouseman (17\%), administrative position
Mediating role of corporate volunteering 


\section{Figure 1}

Model of work engagement based on work characteristics (corporate volunteering) and employee characteristics (entrepreneurial attitude, gender, and seniority) in the context of the public vs. business sector

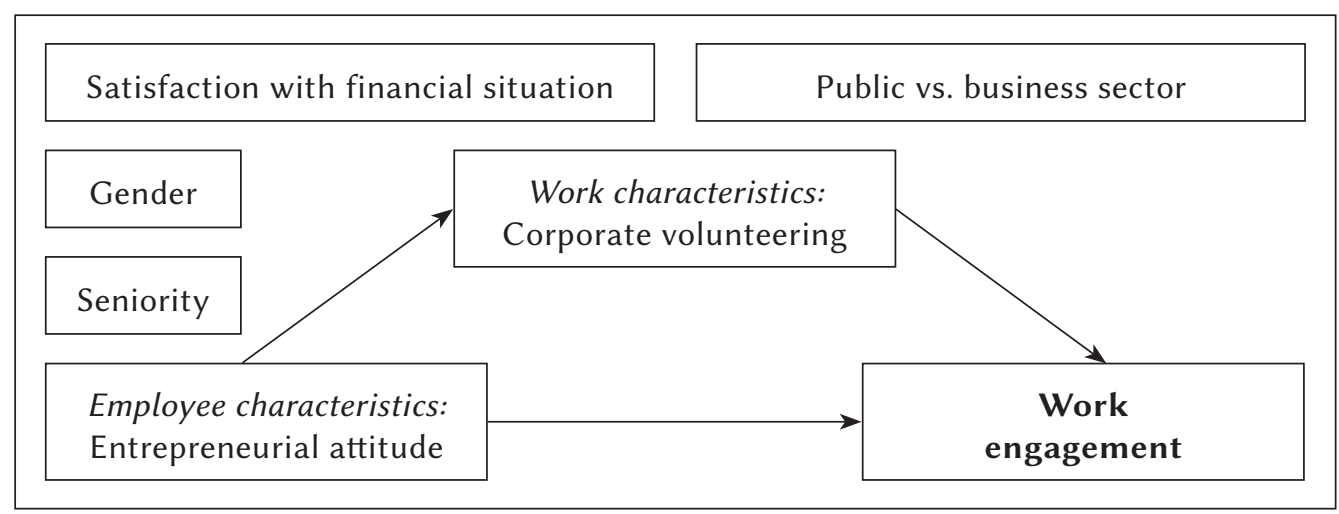

(3.3\%), IT specialist (3.3\%), forester (3.3\%) and other $(8 \%)$. Positions in the business sector $(n=81)$ were: human resources/controlling/PR/logistics/IT specialist (49\%), managerial position (17\%), production (14\%), office worker (9\%), IT worker accountant (5\%), purse maker $(3 \%)$, teacher $(2 \%)$, doctor $(1 \%)$.

Women represented $42 \%$ of the sample $(n=47)$ and men 58\% $(n=64)$. Respondents' age ranged from 23 to $61(M=37.50, S D=9.25)$. Respondents' seniority ranged from 1 to 42 years of work experience. Women were significantly older $(M=39.70, S D=9.73)$ than men $(M=35.87, S D=8.61), Z=-2.24, p=.025$. However, they did not differ with regard to seniority and employment in the public/business sector.

\section{RESEARCH TOOLS}

The Scale of Corporate Volunteering. Corporate volunteering is understood as the frequency of initiatives requiring personal engagement in volunteering activities initiated by the organization (instead of an employee him/herself). Respondents determined the frequency of such activities being undertaken over the past 12 months on a 5 -point scale. The scale ranged from a (never), b (once), c (twice), d (3-5 times) to e (always). Responses were coded on a 0-4 scale. The measurement applies to a specific behavior in a determined period of time. Therefore, the assessment pertains to the behavioral aspect of corporate volunteering instead of the emotional or cognitive one.

Utrecht Work Engagement Scale (UWES). Work engagement was measured by means of the UWES questionnaire (Schaufeli \& Bakker, 2003) in a 17-item version. Respondents used a 0-6 scale with the following labels: 0 (never), 1 (almost never/a few times a year or more seldom), 2 (seldom/once a month or more seldom), 3 (sometimes/a few times a month), 4 (very frequently/ once a week), 5 (frequently/a few times a week), 6 (al- ways/every day). The UWES questionnaire consisted of three subscales: Vigor, Absorption, Dedication.

Entrepreneurial Attitude Orientation questionnaire. In order to examine the entrepreneurial attitude, the Entrepreneurial Attitude Orientation questionnaire (Robinson et al., 1991) in the Polish adaptation was applied (Ochnik, 2016). The analysis exploited an abridged 31-item version $(\alpha=.95)$. This version proved to offer higher reliability when compared with the full version (75 items, $\alpha=.83$ ). Respondents answered on a 1-10 scale. The result emerged from the sum of responses. The entrepreneurial attitude was viewed as a unidimensional construct, which is also advised by the authors of the scale (Robinson et al., 1991).

The Scale of Satisfaction with Financial Situation. A single item Scale of Satisfaction with Financial Situation was applied with scores in the range 1-5. The scale was labeled as follows: 1 (extreme dissatisfaction), 5 (extreme satisfaction). Satisfaction was a subjective cognitive assessment of the respondent and did not pertain to objective salary values. The study also included a socio-demographic questionnaire concerning gender, age, seniority and public vs. business sector of employment.

\section{RESULTS}

In the study the SPSS software was used. The analysis encompassed correlations, significance of differences, linear regression, and mediation by means of the Cohen and Cohen method. In addition, descriptive statistics of the surveyed variables were presented.

Table 1 outlines the descriptive statistics of the surveyed variables for the whole scales as the sum of points of all items.

The average value of responses for the work engagement scale was $3.98(S D=0.89)$. The value may be considered as an average result. The average value 
of the Vigor subscale was $4.12(S D=1.03)$, the Dedication subscale $4.35(S D=1.04)$, and the Absorption subscale $4.01(S D=1.05)$. The results for all subscales may be considered as average.

In the sample, $54 \%(n=60)$ of respondents were involved in corporate volunteering which requires personal engagement during the past 12 months, including $11 \%(n=12)$ who are always involved, $16 \%(n=18)$ involved 3-5 times a year, 17\% $(n=19)$ involved twice a year, and $10 \%(n=11)$ involved once a year. The remaining $46 \%(n=51)$ did not become involved in corporate volunteering during the past 12 months.

Average score for responses concerning the entrepreneurial attitude scale was $7.36(S D=1.26)$. When compared with the results concerning the entrepreneurial attitude among the students of management $(M=6.54, S D=1.07)$ (Ochnik, 2018), Cohen's coefficient $d$ revealed that those employed were characterized by a significantly higher entrepreneurial attitude level. Cohen's $d$ indicated that the difference in scores was average $(d=0.69)$.

Satisfaction with financial situation scored above average. Radically low satisfaction was voiced by $1 \%$ of respondents $(n=1)$, low satisfaction by $9 \%$ $(n=10)$, average satisfaction was declared by $42 \%$ $(n=49)$, and the highest satisfaction by $37 \%(n=41)$. Very high satisfaction was voiced by $11 \%(n=12)$.

Pearson's $r$ coefficient was applied in order to verify correlations among variables (Table 2).

The analysis of correlations revealed that engagement has a low positive correlation with the frequency of corporate volunteering and a high positive correlation with the entrepreneurial attitude. The relationship between corporate volunteering and the entrepreneurial attitude is positive but weak. Satisfaction with financial situation has an average positive correlation with work engagement and corporate volunteering and a low positive correlation with the entrepreneurial attitude. It has no significant relationship with age and seniority. However, a negative correlation may be inferred. Seniority has an average negative correlation with corporate volunteering, and age has a low negative correlation. Both age and seniority have no significant relationship with work engagement.

The analysis of gender differences by means of Student's $t$-test revealed that respondents' gender did not significantly diversify the following: work engagement and its subscales (Vigor, Dedication, Absorption) $(p>.05)$, corporate volunteering requiring

\section{Table 1}

Descriptive statistics $(N=111)$

\begin{tabular}{lrrrr}
\hline Variables & $M$ & $S D$ & Min & Max \\
\hline Work engagement & 67.74 & 15.12 & 6 & 92 \\
Vigor & 24.74 & 6.19 & 2 & 35 \\
Dedication & 21.79 & 5.20 & 0 & 30 \\
Absorption & 24.08 & 6.30 & 4 & 36 \\
Corporate volunteering & 1.36 & 1.43 & 0 & 4 \\
Entrepreneurial attitude orientation & 228.14 & 39.11 & 99 & 300 \\
Satisfaction with financial situation & 3.48 & 0.84 & 1 & 5 \\
\hline
\end{tabular}

\section{Table 2}

A correlation matrix between work engagement, corporate volunteering, entrepreneurial attitude orientation, seniority, age, and satisfaction with financial situation with Pearson's r coefficient $(N=111)$

\begin{tabular}{|c|c|c|c|c|c|c|}
\hline Variables & 1 & 2 & 3 & 4 & 5 & 6 \\
\hline 1. Work engagement & - & & & & & \\
\hline 2. Corporate volunteering & $.36^{* * *}$ & - & & & & \\
\hline 3. Entrepreneurial attitude orientation & $.65^{* * *}$ & $.29^{* *}$ & - & & & \\
\hline 4. Seniority & -.05 & $-.31^{* *}$ & -.07 & - & & \\
\hline 5. Age & .00 & $-.22^{*}$ & .01 & $.87^{* * *}$ & - & \\
\hline 6. Satisfaction with financial situation & $.32^{* * *}$ & $.38^{* * *}$ & $.23^{* *}$ & -.12 & -.05 & - \\
\hline
\end{tabular}

Note. ${ }^{*} p<.05,{ }^{* *} p<.01,{ }^{* * *} p<.001$ 
personal involvement in the past 12 months $(p>.05)$, entrepreneurial attitude $(p>.05)$, and satisfaction with financial situation $(p>.05)$.

Subsequently, the analysis of the significance of sector type differences (public vs. business sector of employment) was conducted by means of Student's $t$-test. The test revealed no significant diversification of seniority $(p>.05)$, corporate volunteering $(p>.05)$, satisfaction with financial situation $(p>.05)$ or entrepreneurial attitude $(p>.05)$. On the other hand, work engagement is slightly diversified by the sector respondents were employed in, $t(109)=-3.40$, $p=.001$. Work engagement of those employed in the public sector $(M=59.50, S D=13.84)$ was lower when compared with those employed in the business sector $(M=69.99, S D=14.56)$, although the effect size was trivial (Cohen's $d=0.01$ ). Additionally, significant but non-trivial differences were observed for the Vigor subscale, $t(109)=-3.24, p=.002$, with medium effect size, Cohen's $d=0.69$. Employees of the public sector $(M=21.73, S D=6.04)$ were significantly less engaged in work in the aspect of vigor compared to the public sector $(M=25.85, S D=5.91)$. The Absorption subscale was also significantly differentiated by the sector type, $t(109)=-4.50, p<.001$, and showed a non-trivial large effect, Cohen's $d=4.26$. Employees of the business sector were far more absorbed in their work $(M=25.59, S D=5.65)$ compared to the public sector $(M=20.00, S D=6.25)$. No significant, sectorspecific differences were noted for the Dedication subscale $(p>.05)$. However, these results ought to be approached with caution due to the low percentage of respondents representing the public sector (27\%).

Next, linear regression analysis was conducted in order to examine the relationship between the independent variable (entrepreneurial attitude) and the dependent variable (work engagement). The model proved statistically significant and with a good fit regarding data, $F(2,103)=74.73, p<.001$. The standardized regression coefficient was $\beta=.25$ and proves the positive correlation between the variables. Stronger entrepreneurial attitude predicts and explains approximately $41 \%\left(R^{2}=.41\right)$ of variance in stronger work engagement.

Several regression analyses were conducted in order to determine the mediating role of corporate volunteering between entrepreneurial attitude orientation and work engagement. Histograms of regression standardized residual have been analyzed and proved the homoscedasticity of the models, which is a criterion of linear regression.

The Cohen and Cohen approach was used in the mediation analysis. First, the linear regression analysis by means of the enter method was conducted. Entrepreneurial attitude is the independent variable. Corporate volunteering is the dependent variable. This stage is necessary to establish the relationship between the dependent variable and the mediator.
The model proved statistically significant with a good fit regarding data, $F(1,104)=9.92, p<.001$. The adjusted $R^{2}$ equals .08 . This denotes that, based on the entrepreneurial attitude, approx. $8 \%$ of variance in corporate volunteering may be predicted. The standardized regression coefficient is $\beta=.29(p=.002)$ and proves the positive correlation between the variables.

Next, the relationship between the potential mediator and the dependent variable (work engagement) was examined. The analysis involved the linear regression. The model proved statistically significant with a good fit regarding data, $F(1,104)=16.47$, $p<.001$. The adjusted $R^{2}$ was .12 . This denotes that, based on the involvement in corporate volunteering, approx. $12 \%$ of variation concerning work engagement may be predicted. The standardized regression coefficient is $\beta=.36(p<.001)$, which proves the positive correlation between variables.

The final stage involved the examination of the correlation between the independent variable (entrepreneurial attitude) and the dependent variable (work engagement) with the mediation of corporate volunteering over the past year. The mediation model had a good fit to the data, $F(2,103)=42.08, p<.001$. The adjusted $R^{2}$ was .44 . This means that the model explains approx. $44 \%$ of the variation for the dependent variable. The standardized regression coefficient indicates that the mediator mediated the relationship between the independent and dependent variable, $\beta=.19, p=.017$. The standardized coefficient for the mediator is $\beta=.59, p<.001$.

An additional Sobel test was conducted in order to verify whether the mediation does indeed occur. The test makes a premise that if both relations - between the independent variable and the mediator, and the mediator and the dependent variable - are statistically significant, then the mediation occurs. The Sobel test examines whether the mathematical product of $\beta$ coefficients between the independent and dependent variables in the mediation model differs significantly from 0 . The result of the test indicated that the impact of partial mediation is significant, $Z=2.28, p=.023$. The $\beta$ coefficients are outlined in Figure 2 .

\section{DISCUSSION}

In this part of the paper, first, results referring to corporate volunteering and its mediating role will be discussed, and secondly, results pertaining to work engagement as the dependent variable in the presented research model will be discussed.

The mediation model revealed considerable significance of the entrepreneurial attitude in terms of explaining both work engagement and corporate volunteering.

Entrepreneurial attitude, as a work characteristic, has a low correlation with satisfaction with financial 


\section{Figure 2}

\section{A mediation model of an entrepreneurial attitude and commitment to work with the mediation role of corporate}

volunteering $(N=111)$

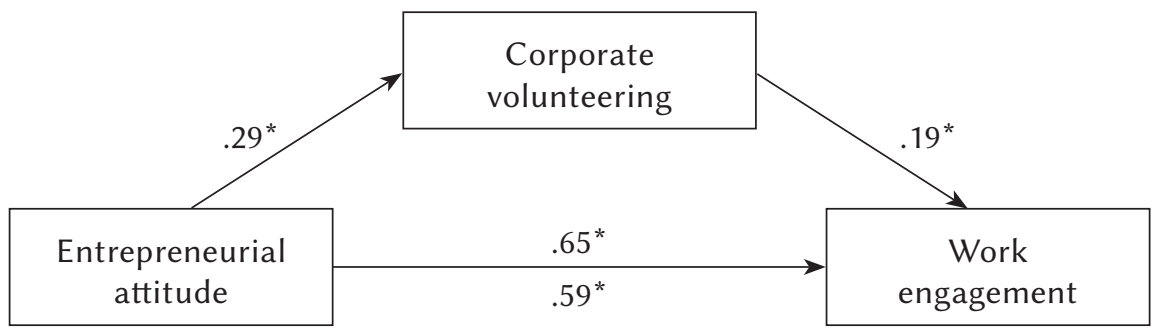

Note. ${ }^{*} p<.05$

Mediating role of corporate volunteering situation, an average correlation with volunteering, and a strong correlation with work engagement. The low correlation with satisfaction with financial situation may be associated with ambition and the pursuit of business achievements. At the same time, employees manifesting a strong entrepreneurial attitude are more likely to be heavily engaged in work and more willing to pursue corporate volunteering. This issue has been continuously neglected in the literature. The results confirm that for an individual involving in corporate volunteering to the benefit of others, the person should manifest an entrepreneurial attitude, i.e. business orientation focused on profits and own needs. This paradox concerning the pursuit of corporate volunteering initiatives determined by the focus on the profit/"business" aspect seems compelling. The issue may be incorporated into the trend examining "selflessness in business", which constitutes a new outlook on people's functioning in business reality from the point of view of cooperation instead of competition (Grant, 2012; Ochnik, 2019). The entrepreneurial attitude is manifested in initiative and the pursuit of achievements. This enhances corporate volunteering and work engagement. On the other hand, relations with corporate volunteering may prove that it constitutes a means for career development. This is especially valid due to fact that the interest in volunteering declines with age.

This study revealed that age and seniority are negatively correlated with corporate volunteering. The results are not convergent with the expected outcomes and contradict findings in the literature. The findings indicate a growing interest in corporate volunteering in relation to age and seniority (Rodell et al., 2017). These discrepancies may be explained by organizational culture, occupational burnout or the belief concerning the sense and understanding of the objective of such initiatives which may also be associated with declining work engagement (Schaufeli $\&$ Bakker, 2003). On the other hand, the lower interest in volunteering at a higher age and seniority indicates that younger employees may consider vol- unteering as an element of career development (a resource). On the other hand, more senior workers may perceive it as an additional burden.

Corporate volunteering plays a mediating role between the entrepreneurial attitude and work engagement. This indicates that people manifesting strong entrepreneurship are more likely to pursue corporate volunteering, which increases their work engagement. Positive correlations between satisfaction with financial situation, entrepreneurial attitude and work engagement, and the pursuit of corporate volunteering, indicate that (depending on a favorable organizational structure), the volunteering may be perceived by employees as a work resource. This may mean that corporate volunteering was associated with good working conditions.

Work engagement was explained well by employees' profile: entrepreneurial attitude, and by work characteristics: corporate volunteering, age, seniority, and public vs. business sector of employment constituted additional surveyed factors. Studies conducted in nine countries indicate a positive, albeit weak relation between work engagement and age (Schaufeli \& Bakker, 2003). However, this study did not reveal a significant correlation in this respect. Work engagement was independent from respondents' age. In addition, gender did not prove to have a significant diversifying effect on work engagement. This was contrary to the global literature, which indicates higher (even though low impact) scores for men (Schaufeli \& Bakker, 2003). Similar results revealing the similarity between male and female employees concerning work engagement were obtained in other Polish studies (Wołpiuk-Ochocińska, 2016). Consequently, the hypothesis regarding the diversifying impact of gender on work engagement was not confirmed. However, the recurring results of Polish studies, whose results differ from those of other countries, reveal the underlying culture-dependence of the issue.

The results pertaining to the diversification of the surveyed variables with regard to the public vs. business sector of employment ought to be approached 
with caution, as the sample was not representative for the public and business sector. In this study, respondents from the public sector manifested lower general work engagement. This was especially valid for the behavioral and energy-related aspects manifesting in an effort being undertaken (Vigor), and in the cognitive aspect in terms of attention focus and work absorption (large effect size). However, in line with another Polish study (Kulikowski, 2016), the emotional aspect of work engagement, which manifests in an individual experiencing the feeling of importance, enthusiasm, inspiration, pride, and challenges at work, was not differentiated by the sector of employment. This means that employees of both the public and business sectors exhibited a similar level of dedication and the work's importance. In addition, this study revealed that, as opposed to the results of other studies (Kulikowski, 2016), their satisfaction with their financial situation was the same.

The study proved the mediating role of corporate volunteering between entrepreneurial attitude and work engagement. It also showed the significance of the role of financial satisfaction. It was positively related to entrepreneurial attitude, corporate volunteering, and work engagement. It additionally showed the role of age and seniority for corporate volunteering frequency, and the lack of seniority and gender effects on work engagement. Therefore, it allowed for positive verification of the proposed research model and enriched psychological aspects of the role of corporate volunteering.

\section{CONCLUSIONS}

The present study confirmed the mediating role of corporate volunteering (one which requires personal involvement) between the entrepreneurial attitude and work engagement. The entrepreneurial attitude proved a vital employee characteristic which has a strong correlation with and predicts both corporate volunteering and work engagement. The entrepreneurial attitude was verified in the work engagement model with the mediating role of corporate volunteering for the first time. The model proved valid and had a good fit.

Gender proved to be insignificant in the model. On the other hand, age, and seniority, as opposed to global studies, proved to have a negative correlation with corporate volunteering but no relationship with work engagement.

When analyzing the results in connection with practical implications, the notable role of the entrepreneurial attitude in recruitment and selection, as a strong predictor of work engagement, ought to be highlighted. In addition, corporate volunteering also deserves attention as a factor having a positive correlation with work engagement. This means that the introduction of corporate volunteering initiatives may enhance work engagement, which has positive implications for the individual and the organization.

\section{STUDY LIMITATIONS}

Several limitations of the study exist. First, purposive sampling was used for the purpose of data collection. From a methodological point of view, random sampling always allows for more accurate measurement and in-depth insights. Although the business sector group was highly diverse in terms of vocational positions, the public sector sample could be more diverse in this area. Secondly, the sample size is too small to draw conclusions about the population of employees. Particularly, the lack of relations between age and work engagement, as well as the negative relation between age and corporate volunteering, requires a further investigation in a larger sample. One should take into consideration the cultural context that might explain different results compared to global research, mostly referring to the Anglo-Saxon work environment. It would also be highly beneficial if the type of position and company size were taken into consideration. Therefore, a larger study within a cultural context should be conducted.

\section{REFERENCES}

Bakker, A. B., \& Bal, M. P. (2010). Weekly work engagement and performance: a study among starting teachers. Journal of Occupational and Organizational Psychology, 83, 189-206. https:// doi.org/10.1348/096317909X402596

Boštjančič, E., Antolović, S., \& Erčulj, V. (2018). Corporate volunteering: Relationship to job resources and work engagement. Frontiers in Psychology, 9, 1884. https://doi.org/10.3389/fpsyg.2018.01884

Choe, K. L., Loo, S. C., \& Lau, T. C. (2013). Exploratory study on the relationship between entrepreneurial attitude and firm's performance. Asian Social Science, 9, 144-149. https://doi.org/10.5539/ass.v9n4p144

Christian, M. S., Garza, A. S., \& Slaughter, J. E. (2011). Work engagement: a quantitative review and test of its relations with task and contextual performance. Personnel Psychology, 64, 89-136. https:// doi.org/10.1111/j.1744-6570.2010.01203.x

Derbis, R., \& Baka, Ł. (2011). Znaczenie wsparcia społecznego i zaangażowania w pracę dla związku stresorów w pracy i wypalenia zawodowego [The role of social support and work engagement in the work stressors-burnout relationship]. Czasopismo Psychologiczne, 17, 277-287.

Douglas, E. J., \& Shepherd, D. A. (2000). Entrepreneurship as a utility maximizing response. Journal of Business Venturing, 15, 231-251. https:// doi.org/10.1016/S0883-9026(98)00008-1 
Grabus, M., \& Rogowska, M. (2016). Uwarunkowania wolontariatu pracowniczego $w$ firmie informatycznej [Volunteer program conditions in an information technology company]. Zarzqdzanie Zasobami Ludzkimi, 1, 91-105.

Grant, A. M. (2012). Giving time, time after time: Work design and sustained employee participation in corporate volunteering. Academy of Management Review, 37, 589-615. https://doi.org/10.5465/amr.2010.0280

Harter, J. K., Schmidt, F. L., \& Hayes, T. L. (2002). Business-unit-level relationship between employee satisfaction, employee engagement, and business outcomes: a meta-analysis. Journal of Applied Psychology, 87, 268-279. https://doi.org/10.1037/00219010.87.2.268

Jones, G., \& Kramar, R. (2010). CSR and the building of leadership capability. Journal of Global Responsibility, 1, 250-259. https://doi.org/10.1108/ 20412561011079380

Judge, T. A., \& Ilies, R. (2002). Relationship of personality to performance motivation: a meta-analytic review. Journal of Applied Psychology, 87, 797-807. https://doi.org/10.1037/0021-9010.87.4.797

Kim, W., Kim, J., Woo, H., Park, J., Jo, J., Park, S. H., \& Lim, S. Y. (2017). The relationship between work engagement and organizational commitment: Proposing research agendas through a review of empirical literature. Human Resource Development Review, 16, 350-376. https://doi.org/10.1177/ 1534484317725967

Krueger Jr, N. F., Reilly, M. D., \& Carsrud, A. L. (2000). Competing models of entrepreneurial intentions. Journal of Business Venturing, 15, 411-432. https:// doi.org/10.1016/S0883-9026(98)00033-0

Kulikowski, K. (2016). Satysfakcja z wynagrodzenia i zaangażowanie w pracę wśród pracowników firm prywatnych i państwowych [Pay satisfaction and work engagement among employees in private and national companies]. Zarządzanie Publiczne, 1, 58-67. https://doi.org/10.15678/ZP.2016.35.1.05

Łaguna, M., Mielniczuk, E., Żaliński, A., \& Wałachowska, K. (2015). Przywiązanie do organizacji i zaangażowanie w pracę - koncepcje teoretyczne i problemy terminologiczne [Organizational commitment and work engagement - theoretical conceptions and terminological problems]. Medycyna Pracy, 66, 277-284. https://doi.org/10.13075/mp.5893.00169

Mitchell, R. K., Busenitz, L., Lant, T., McDougall, P. P., Morse, E. A., \& Smith, J. B. (2002). Toward a theory of entrepreneurial cognition: Rethinking the people side of entrepreneurship research. Entrepreneurship Theory and Practice, 27, 93-104. https:// doi.org/10.1111/1540-8520.00001

Ochnik, D. (2016). Does media information about economic crisis modify entrepreneurial attitude? Marketing i Rynek, 23, 19-26.

Ochnik, D. (2018). Entrepreneurial attitude and personality as predictors of leadership vocational interests in men and women. Proceedings of 6th International Conference Innovation Management, Entrepreneurship and Sustainability (IMES) (pp. 857-866). University of Economics.

Ochnik, D. (Ed.) (2019). Selflessness in business. Vernon Press.

Robinson, P. B., Stimpson, D. V., Huefner, J. C., \& Hunt, H. K. (1991). An attitude approach to the prediction of entrepreneurship. Entrepreneurship Theory and Practice, 15, 13-32. https:// doi.org/10.1177/104225879101500405

Rodell, J. B., Booth, J. E., Lynch, J. W., \& Zipay, K. P. (2017). Corporate volunteering climate: Mobilizing employee passion for societal causes and inspiring future charitable action. Academy of Management Journal, 60, 1662-1681. https:// doi.org/10.5465/amj.2015.0726

Rodell, J. B., Breitsohl, H., Schröder, M., \& Keating, D. J. (2016). Employee volunteering: a review and framework for future research. Journal of Management, 42, 55-84. https://doi.org/10.1177/0149206315614374

Schaufeli, W. B., \& Bakker, A. B. (2003). Utrecht Work Engagement Scale: Preliminary manual. Utrecht: Occupational Health Psychology Unit, Utrecht University.

Schaufeli, W. B., Taris, T. W., \& Van Rhenen, W. (2008). Workaholism, burnout, and work engagement: Three of a kind or three different kinds of employee well-being? Applied Psychology, 57, 173-203. https://doi.org/10.1111/j.1464-0597.2007.00285.x

Van Knippenberg, D. (2000). Work motivation and performance: a social identity perspective. Applied Psychology, 49, 357-371. https://doi.org/10.1111/ 1464-0597.00020

Wojciszke, B. (2011). Psychologia spoteczna [Social psychology]. Wydawnictwo Naukowe Scholar.

Wołpiuk-Ochocińska, A. (2016). Zaangażowanie w pracę i przywiązanie organizacyjne pracowników w przedsiębiorstwach o różnym poziomie kultury bezpieczeństwa pracy [Work engagement and organization commitment employees from organizations with different level of labour safety culture]. Zeszyty Naukowe Wyższej Szkoty Zarzadzania Ochrona Pracy w Katowicach, 1, 135-148.

Wood, E. (2007). "What about me?" The importance of understanding the perspective of non-managerial employees in research on corporate citizenship. In F. den Hond, F. G. A. de Bakker, \& P. Neergaard (Eds.), Managing corporate social responsibility in action: Talking, doing and measuring (pp. 111-125). Ashgate Publishing Limited.

Zalewska, A. M. (2020). Konflikty praca-rodzina i rodzina-praca a zdrowie: ochronna rola zaangażowania i zadowolenia z pracy [Work-family and family-work conflicts and health: The protective role of work engagement and job-related subjective well-being]. Medycyna Pracy, 71, 33-46. https://doi.org/10.13075/mp.5893.00908
Mediating role of corporate volunteering 